\title{
Synthesis and Characterization of Some New Monemer and Polymers Containing Hetero Cyclic Rings With Study of Their Physical Properties.
}

\author{
Ibtisam K. Jassim* \\ Iman M. M. Hassan** \\ *Department of Chemistry, College of Education Ibn-Al-Haitham, University of \\ Baghdad, Iraq. \\ **Department of Chemistry, College of Science for Women, University of Baghdad, \\ Iraq.
}

Received 17/9/2015

Accepted 20/12/2015

(1) $\Theta$

NoDerivatives 4.0 International Licens

under a Creative Commons Attribution-NonCommercial-

\begin{abstract}
:
Number of new polyester and polyamide are prepared as derivatives from 5,5 (1,4-phenylene)-bis-(1,3,4-thiadiazole-2-amine) $\left[\mathrm{C}_{1}\right]$, three series of heterocyclic compounds were synthesized.The first series includes the Schiff base $\left[\mathrm{C}_{2}\right]$ prepared from the reaction between compound $\left[\mathrm{C}_{1}\right]$ with p-hydroxy benzaldehyde in presence of acetic acid and absolute ethanol, then these derivatives have reaction with maleic anhydride, phthalic anhydride and sodium azide, respectively to obtain the compounds $\left[\mathrm{C}_{3-5}\right]$ contaning (oxazepine and tetrazole) rings. The third series of compounds $\left[\mathrm{C}_{1^{-5}}\right]$ has transformed to their polymers $\left[\mathrm{C}_{6^{-}}{ }^{-15}\right]$ by reaction with adipoyl chloride and glutroyl chloride, respectively. The reaction was followed by T.L.C and identified by FT-IR , ${ }^{1} \mathrm{H}-\mathrm{NMR}$,C.H.N analysis , softening point, viscosity, TGA , DSC and X-ray.
\end{abstract}

Key words: Heterocyclic rings , 1,3,4-Thiadiazole derivatives, Thermal properties.

\section{Introduction:}

Numerous papers in literature describing the reactions of various compounds with polymers in order to change the properties of the polymers $[1,2]$, often these reactions have resulted in significant change in such properties as flammability, solubility, thermal degradation and strength[2]. 5,5-(1,4phenylene)-bis-(1,3,4-thia- diazole-2amine) consititute an important class of compounds having awide number of variously subsitituted 1,3,4-thiadiazole derivatives $[3,4]$, the industerial application in view of these observations synthesis of series of derivatives of 1,3,4-thiadiazole with its polymers has been synthesized[5].

\section{Materials and Methods:}

All the chemicals used were supplied by (Merk, Fluka and BDH), the solvent was purified by distillation and dried with calcium chloride. Melting point was determined on Gallenkamp (melting point) apparatus and was uncorrected, softening point,FTIR spectra were 
designated by (SHIMADZU) / FTIR 8300 spectrometer as $\mathrm{KBr}$. disc, result were given in $\left(\mathrm{cm}^{-1}\right),{ }^{1} \mathrm{H}-\mathrm{NMR}$ spectra were recorded at 200.13 and $50.32 \mathrm{MH}_{\mathrm{Z}}$ respectively in $\left(D M S O-d_{6}\right)$ which were reported in part per million (ppm) down field from internal tetramethylsilane (TMS) (chemical shift in $\delta$ values)In Tahran university. Elemental analysis was run by using a perkin - Elmer RE2400 (C.H.N) analyzer, ${ }^{1}$ H-NMR, TGA, DSC, X-Ray, viscosity and microbial study All analyses were performed in center service laboratorylcollege of Education for pure service-Ibn-Al-Haitham University of Baghdad.

Prepration of 5,5 -(1,4-phenyl -ene)bis(1,3,4-thiadiazole-2-amine) $\left[\mathrm{C}_{1}\right]$

A mixture of terephthaldehyde $(0.01$ $\mathrm{mol})$, thiosemicarbazide $(0.02 \mathrm{~mol})$ and phosphorus oxy chloride $(25 \mathrm{~mL})$ was refluxed for (4 hrs),then cooled and added distulled water with continuing refluxing $(1 \mathrm{hr})$, sodium hydroxide added until mixture $\mathrm{pH}=8$, diluted with distlled water. The precipitate filtered, recrystallized from ethanol. Physical properties are listed inTable (1) and spectra data listed in Table (3).

Prepration of $4,4^{\prime}-\left(\left(\left(5,5^{\prime}-(1,4-\right.\right.\right.$ phenylene)-bis-(1,3,4-thiadiazole-5,2diyl))-bis-(azanylylidene))-bis(methanylylidene))diphenol $\left[\mathrm{C}_{2}\right]$

A mixture of compound $\left[\mathrm{C}_{1}\right](0.033$ mol), p-hydroxybenzaldehyde (0.066 $\mathrm{mol})$, in absolute ethanol $(25 \mathrm{~mL})$ and (3-5) drops of glacial acetic acid, the mixture was refluxed for ( $1 \mathrm{hr})$. After the end of reaction (checked by TLC), cooling the precipitate then filtered it, collected then washed with cold ethanol and recrystallized from ethanol. Physical properties are listed in Table (1) and spectra data listed in Table(3).

Prepration of $\quad\left[3,3^{\prime}-\left(5,5^{\prime}-(1,4-\right.\right.$ phenylene)-bis-(1,3 ,4-thiadiazole5,2diyl))bis-(2-(4-hydroxy phenyl )2,3dihydro-1,3-oxazepine-4,7 -dione)] $\left[\mathrm{C}_{3}\right] ; \quad 4,4^{\prime}-\left(5,5^{\prime}-(1,4-\right.$ phenylene $)$-bis(1,3,4-thiadiazole-5,2diyl))bis(3hydroxyphenyl)-3,4dihydro benzo[e][1,3] oxazepine-1,5dione) $\left[\mathrm{C}_{4}\right]$ and $4,4^{\prime}-\left(1,1^{\prime}-\left(5,5^{\prime}-(1,4-\right.\right.$ phenylene)-bis-(1,3,4-thiadiazole-5,2diyl))-bis-(4,5-dihydro-1H-tetrazole5,1-diyl))diphenol [ $\mathrm{C}_{5}$ ]

A mixture of $\left[\mathrm{C}_{2}\right](0.01 \mathrm{~mol})$ dissolved in dry benzene $(20 \mathrm{~mL})$ with malic anhydride $(0.02 \mathrm{~mol})$, phathalic anhydride $(0.02 \mathrm{~mol})$, sodium azide $(0.02 \mathrm{~mol})$ and dry THF $(20 \mathrm{~mL})$ were refluxed for ( $5 \mathrm{hrs}$ ) (checked by TLC). Excess solvent was distlled,filtered of and recrystallized from ethanol to obtain the compounds $\left[\mathrm{C}_{3-5}-5\right.$. Physical properties are listed in Table (1) and spectra data listed in Table(3).

The polymerization of $\left[\mathrm{C}_{1}-\mathrm{C}_{5}\right]$ compounds.

The polymerization of compounds $\left[\mathrm{C}_{1^{-}}\right.$ 5] was carried out in dry pyridine by using adipoyl chloride, glutroyl chloriede respectively. The mixture was refluxed in water bath. After $(6 \mathrm{hrs})$ (checked by TLC), the contents of the flask were poured into ice distilled water to precipitate the polymers $\left[\mathrm{C}_{6^{-}}{ }_{15}\right]$. Physical properties are listed in Table (2) and spectra data listed in Table (3). 

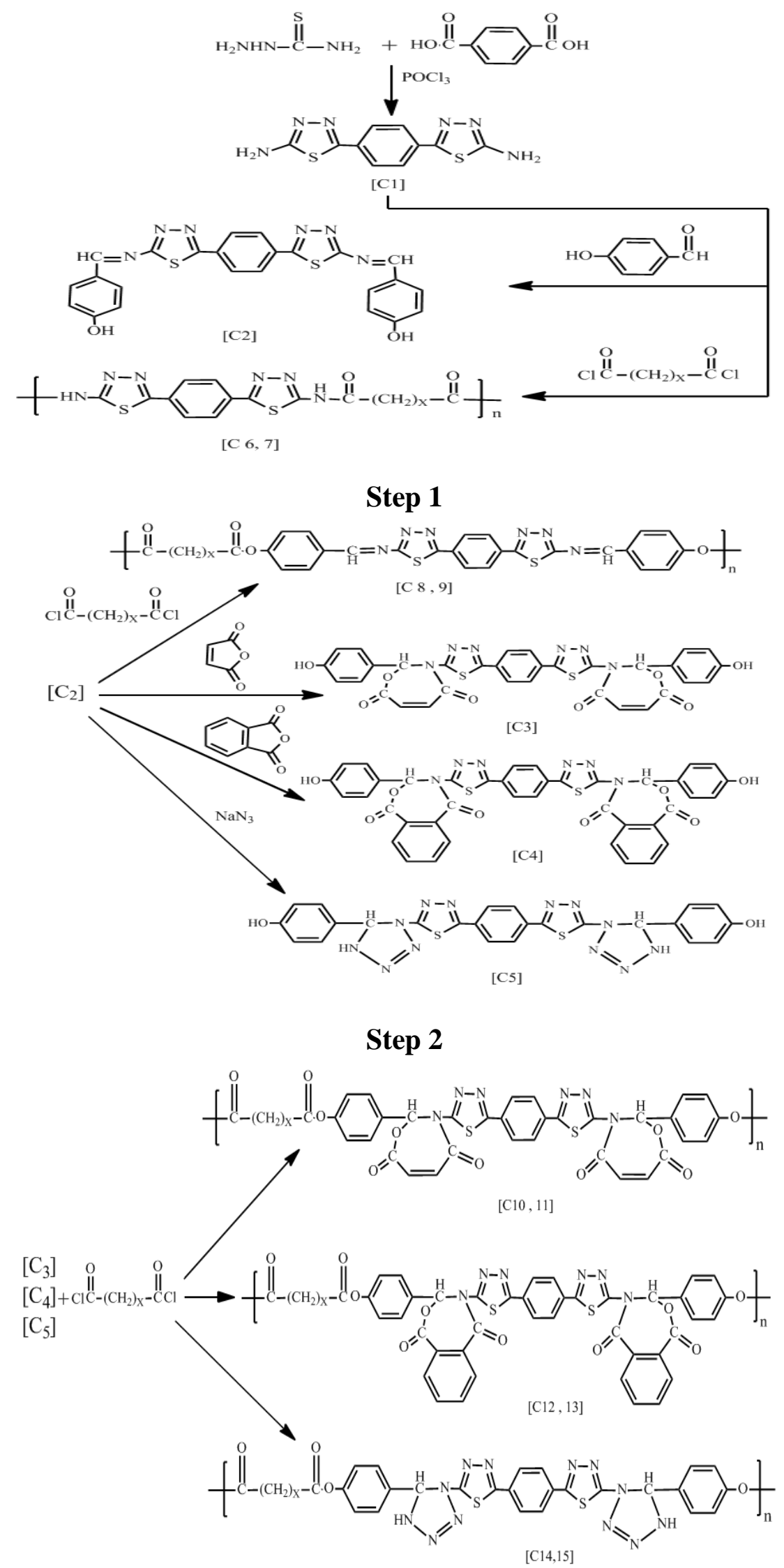

Step 3

Scheme (1) : Synthetic steps in this work ( where $X=3,4$ ). 


\section{Results and Discussion:}

Some physical properties together with analytical and spectral data of the prepared compounds are summarized in Table (1,2 and 3). All prepared polymers were soluble in all common solvents such as Dimethylformamide, Dimethyl sulfoxide, Methyl chloride, Cyclohexane. The viscosity measurment of synthesized polymers was determined by using viscometer (type Ubbelohod viscometer) which was placed in water bath at $40^{\circ} \mathrm{C}$, Table 2 .
Table (1) : Physical properties of the prepared compound [C1-5].

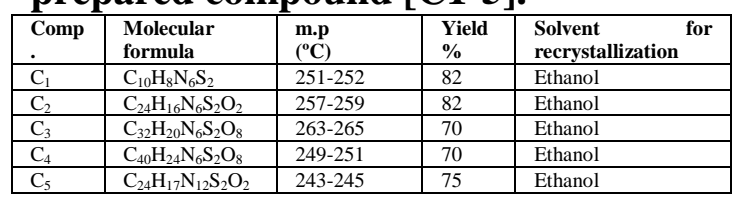

Table (2): Physical properties of the prepared polymers [C6-15].

\begin{tabular}{|c|c|c|c|c|c|}
\hline Comp. & S.P $\left({ }^{\circ} \mathbf{C}\right)$ & $|\eta| g m / I L$ & Comp. & S.P $\left({ }^{\circ} \mathbf{C}\right)$ & $\begin{array}{l}\operatorname{l\eta } \\
\operatorname{lgm} / \mathbf{I L}\end{array}$ \\
\hline $\mathrm{C}_{6}$ & $225-235$ & 2.20 & $\mathrm{C}_{11}$ & $>300$ & 0.21 \\
\hline $\mathrm{C}_{7}$ & $223-233$ & 2.14 & $\mathrm{C}_{12}$ & $>300$ & 1.35 \\
\hline $\mathrm{C}_{8}$ & $250-260$ & 0.25 & $\mathrm{C}_{13}$ & $>300$ & 1.25 \\
\hline $\mathrm{C}_{9}$ & $249-259$ & 0.23 & $\mathrm{C}_{14}$ & $>300$ & 1.50 \\
\hline $\mathrm{C}_{10}$ & $>300$ & 0.25 & $\mathrm{C}_{15}$ & $279-289$ & 1.48 \\
\hline
\end{tabular}

Table (3) : IR, ${ }^{1}$ HNMR Spectra and C.H.N.S analysis of compounds [C1-5].

\begin{tabular}{|c|c|c|c|c|c|c|c|c|c|}
\hline \multirow{2}{*}{$\begin{array}{l}\text { Comp. } \\
\text { No. }\end{array}$} & \multicolumn{4}{|c|}{ Major absorption $\mathbf{c m}^{-1}$} & \multirow{2}{*}{${ }^{1}$ HNMR Spectrum } & \multicolumn{4}{|c|}{$\begin{array}{l}\text { \% Elemental analysis } \\
\text { Calc. (Found) }\end{array}$} \\
\hline & $\mathrm{v} \mathrm{NH_{2 }}$ & $\mathrm{VOH}$ & $v \mathrm{C}=\mathbf{O}$ & $v \mathrm{C}=\mathrm{N}$ & & C & $\boldsymbol{H}$ & $\boldsymbol{N}$ & $S$ \\
\hline $\mathrm{C}_{1}$ & 3471 & ----- & ----- & 1598 & -------- & $\begin{array}{l}43.48 \\
(44.20)\end{array}$ & $\begin{array}{l}2.90 \\
(3.18)\end{array}$ & $\begin{array}{l}30.44 \\
(31.60)\end{array}$ & $\begin{array}{l}23.19 \\
(24.25)\end{array}$ \\
\hline $\mathrm{C}_{2}$ & ----- & 3489 & 1728 & 1681 & $\begin{array}{l}\text { Single } \delta=(10.3-10.5) \\
\text { ppm for }(\mathrm{H}-\mathrm{OH}) \text { and } \delta= \\
\text { ( } 7.8-8) \text { ppm for aromatic } \\
\text { ring }\end{array}$ & $\begin{array}{l}59.50 \\
(60.20)\end{array}$ & $\begin{array}{l}3.31 \\
(4.10)\end{array}$ & $\begin{array}{l}17.36 \\
(18.20)\end{array}$ & $\begin{array}{l}13.22 \\
(14.10)\end{array}$ \\
\hline $\mathbf{C}_{3}$ & ----- & 3474 & 1728 & ----- & --------- & $\begin{array}{l}56.47 \\
(57.10)\end{array}$ & $\begin{array}{l}2.94 \\
(3.10)\end{array}$ & $\begin{array}{l}12.35 \\
(13.00)\end{array}$ & $\begin{array}{l}9.41 \\
(10.20)\end{array}$ \\
\hline $\mathrm{C}_{4}$ & ----- & 3420 & 1735 & ----- & -------- & $\begin{array}{l}61.54 \\
(62.10)\end{array}$ & $\begin{array}{l}3.08 \\
(4.00)\end{array}$ & $\begin{array}{l}10.77 \\
(11.12)\end{array}$ & $\begin{array}{l}8.21 \\
(9.00)\end{array}$ \\
\hline $\mathrm{C}_{5}$ & ----- & 3390 & 1712 & ----- & $\begin{array}{l}\text { Single } \delta=(10-10.8) \mathrm{ppm} \\
\text { for }(\mathrm{H}-\mathrm{OH}), \delta=(12.9) \\
\text { ppm for }(\mathrm{N}=\mathrm{N}), \delta= \\
(7.2-7.8) \quad \mathrm{ppm} \text { for } \\
\text { aromatic ring, } \delta=(8.2- \\
8.5) \mathrm{ppm} \text { for tetrazole } \\
\text { and } \delta=(10.04) \mathrm{ppm} \text { for } \\
(1 \mathrm{H}, \mathrm{NH})\end{array}$ & $\begin{array}{l}50.62 \\
(51.00)\end{array}$ & $\begin{array}{l}2.99 \\
(3.30)\end{array}$ & $\begin{array}{l}29.53 \\
(30.80)\end{array}$ & $\begin{array}{l}11.25 \\
(12.07)\end{array}$ \\
\hline
\end{tabular}

\section{FT-IR Spectra:}

The FT-IR spectrum of compound $\left[\mathrm{C}_{1}\right]$ exhibited significant two bands in the region $\left(3471 \mathrm{~cm}^{-1}\right)[6]$ which attributed to the stretching vibration bands of $\mathrm{NH}_{2}$ group beside this a band at about $\left(1598 \mathrm{~cm}^{-1}\right)$ due to streching vibration band of cyclic imine group $\mathrm{C}=\mathrm{N}$ [7,8]. The FT-IR spectrum of compound $\left[\mathrm{C}_{2}\right]$ by disappearance of $v \mathrm{NH}_{2}$ absorption band combined with appearing of $\mathrm{vOH}$ absorption band at
(3470 $\mathrm{cm}^{-1}$ ) [6], also absorption band appeared at $\left(1681 \mathrm{~cm}^{-1}\right)[8]$ due to $\mathrm{vC}=\mathrm{N}$ of schiff base. FT-IR spectra show a clear strong absorption band indicating ester formation at (1750-1765) $\mathrm{cm}^{-1}$ and (1180-1199) $\mathrm{cm}^{-1}$ for $\mathrm{VC}=\mathrm{O}$ and $\mathrm{C}-\mathrm{O}$ group respectively due to polyester [9]. Also clear absorbition band for $v \mathrm{~N}-\mathrm{H}$ of amide at aboute (3196-3220) $\mathrm{cm}^{-1}$ $v \mathrm{C}=\mathrm{O}$ of amide at (1712-1735) $\mathrm{cm}^{-1}$ [7], as shown in Figures (1-5). 


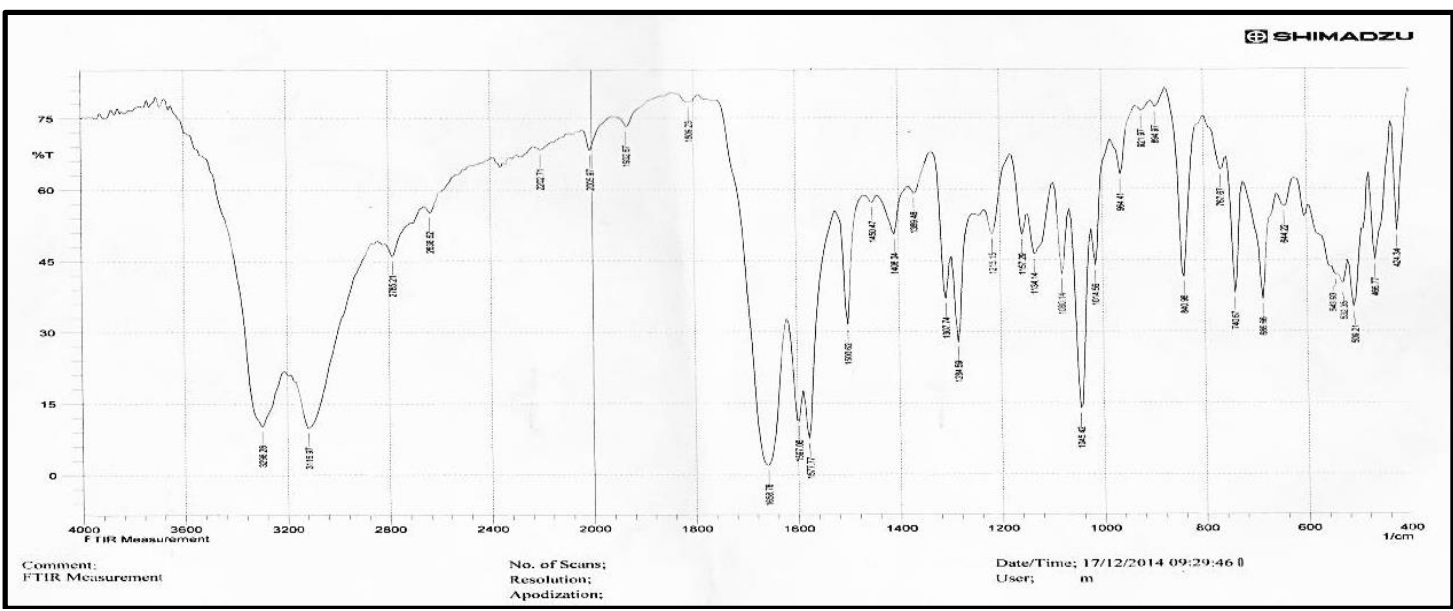

Fig.(1) : FT-IR of [ $\left.\mathrm{C}_{1}\right]$.

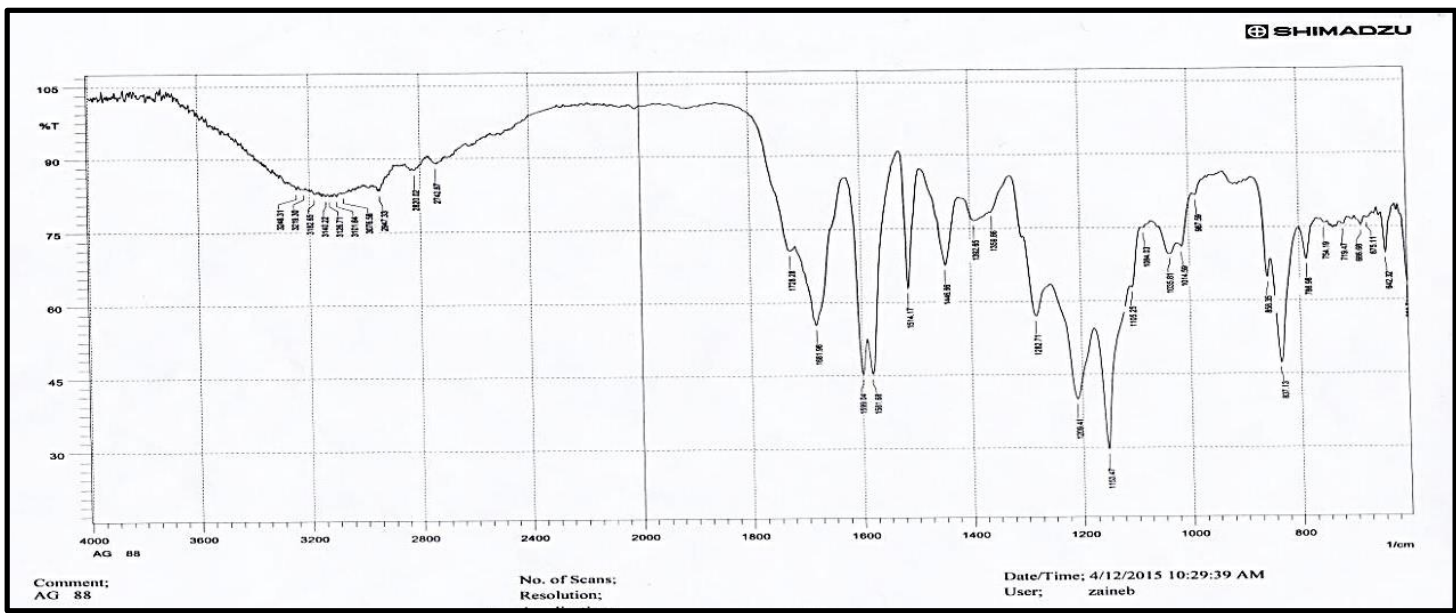

Fig.(2) : FT-IR of [ $\left.\mathrm{C}_{2}\right]$.

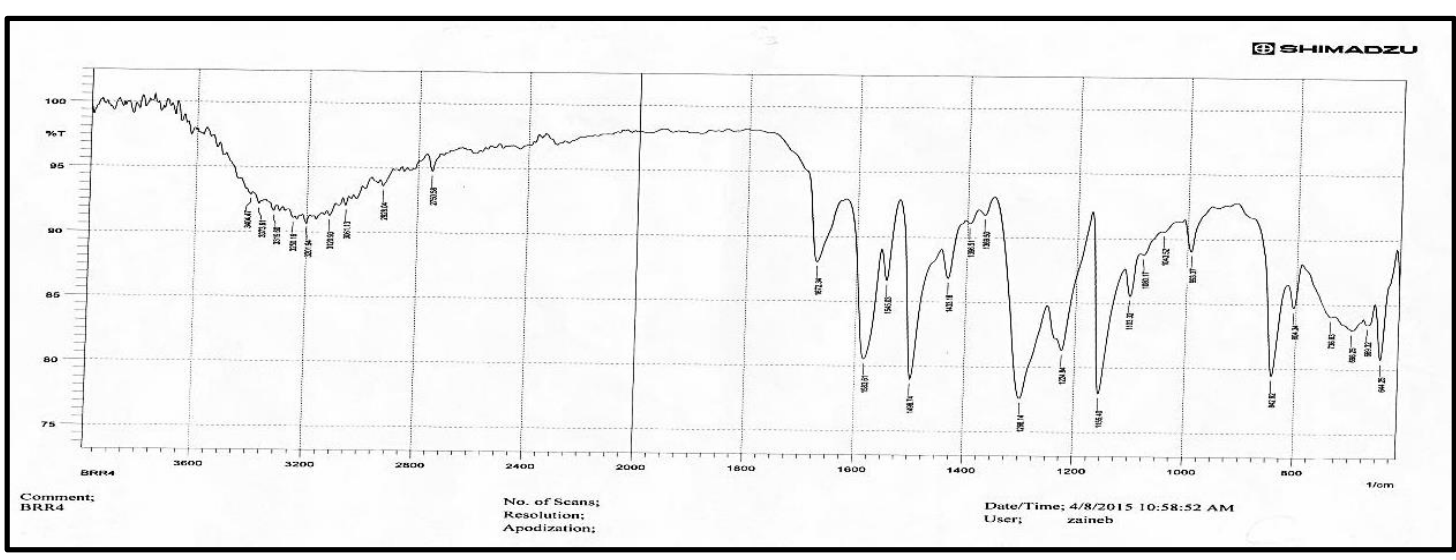

Fig.(3) : FT-IR of $\left[\mathrm{C}_{3}\right]$. 


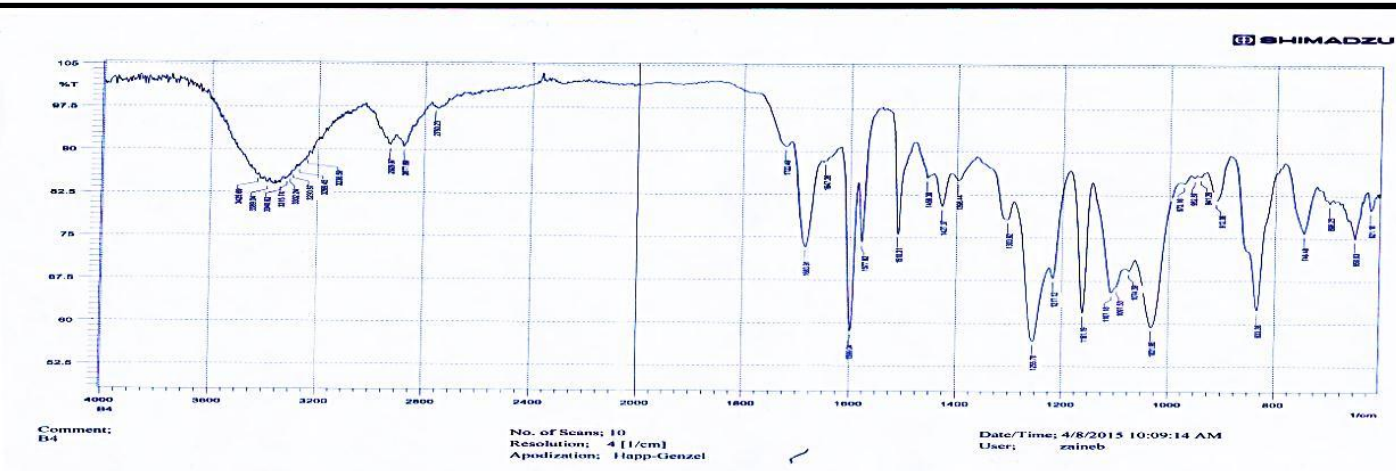

Fig.(4) : FT-IR of [ $\left.\mathrm{C}_{4}\right]$.

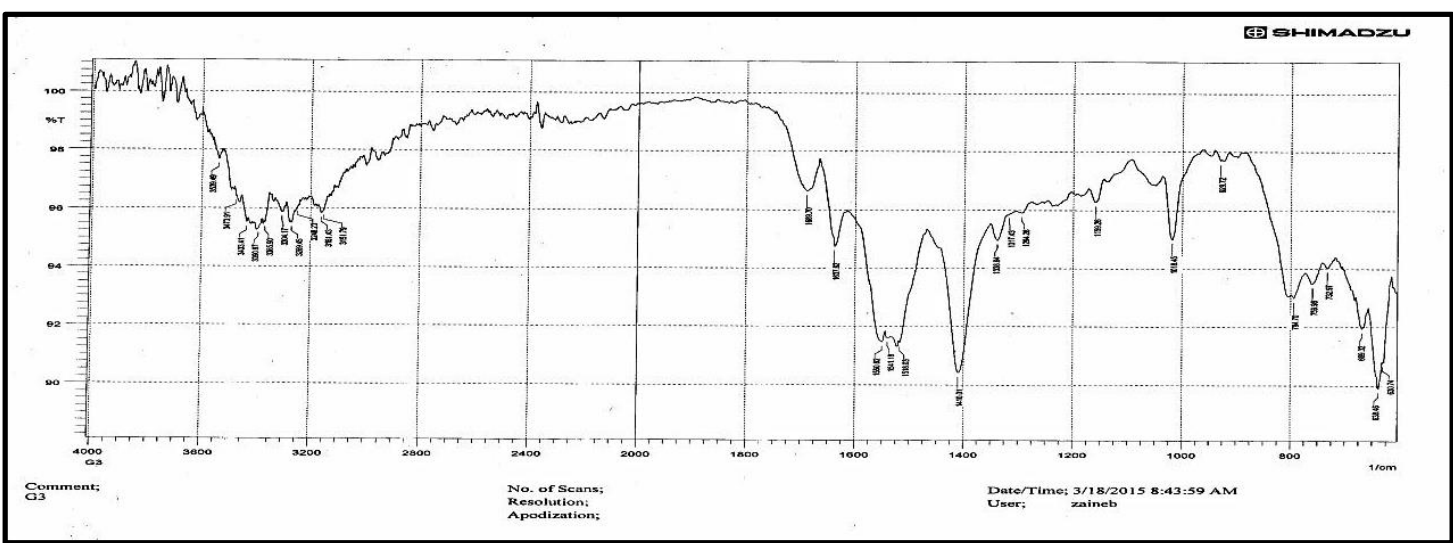

Fig.(5) : FT-IR of [C $\left.\mathrm{C}_{5}\right]$.

\section{${ }^{1}$ HNMR Spectra:}

${ }^{1} \mathrm{HNMR}$ spectrum for $\left[\mathrm{C}_{2}\right]$, Figure (6), shows a singlet at $\delta=(10.3-$ 10.5) $\mathrm{ppm}$ for $(\mathrm{H}-\mathrm{OH})$ and $\delta=(7.8-8)$ ppm for aromatic ring, while ${ }^{1} \mathrm{HNMR}$ spectrum for $\left[\mathrm{C}_{5}\right]$ Figure (7), shows a

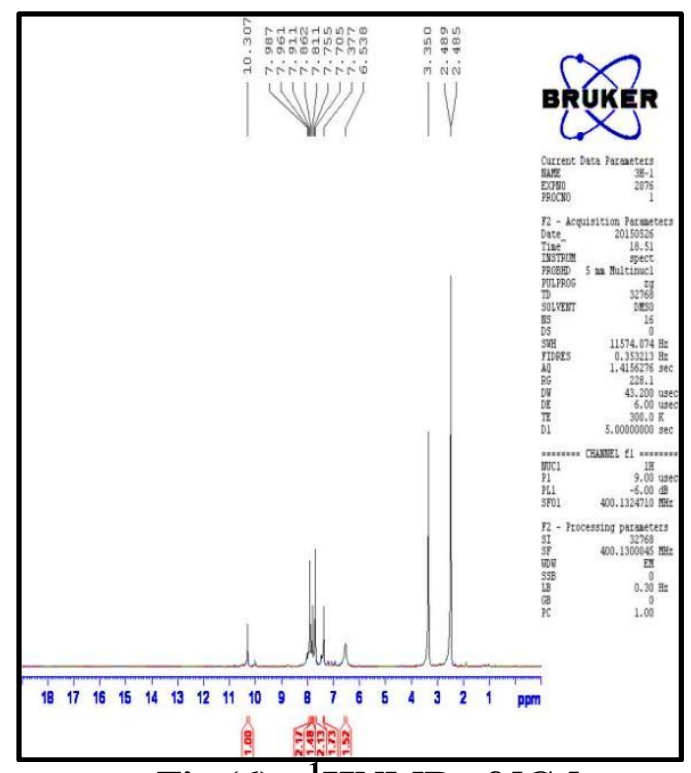

Fig.(6): ${ }^{\mathrm{H}} \mathrm{HNMR}$ of $\left[\mathrm{C}_{2}\right]$. singlet at $\delta=(10-10.8) \mathrm{ppm}$ for $(\mathrm{H}-\mathrm{OH})$, $\delta=(12.9) \mathrm{ppm}$ for $(\mathrm{N}=\mathrm{N}), \delta=(7.2-7.8)$ $\mathrm{ppm}$ for aromatic ring,$\delta=(8.2-8.5)$ $\mathrm{ppm}$ for tetrazole and $\delta=(10.04)$ ppm for $(1 \mathrm{H}, \mathrm{NH})$.

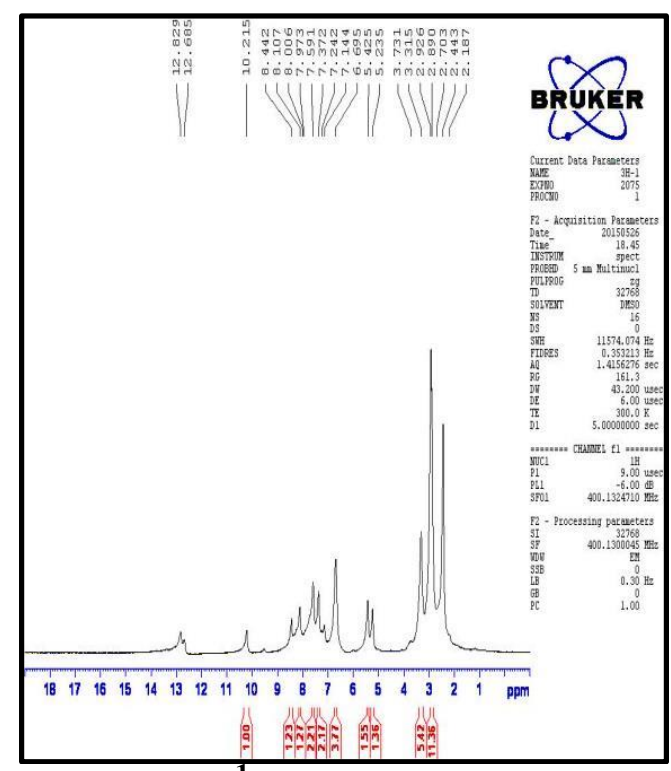

Fig.(7): ${ }^{1}$ HNMR of $\left[\mathrm{C}_{5}\right]$. 


\section{Thermal stability:}

Thermal stability of the prepared polyester, polyamide was investigated by thermogravimetric analysis (TGA and DSC).The data showed that the weight of polymer $\left[\mathrm{C}_{6}\right]$ fell slightly at temperature $(127-423)^{\circ} \mathrm{C}$, while weight of polymer $\left[\mathrm{C}_{8,12}\right]$ fell slightly at range of temperature $(157-513)^{\circ} \mathrm{C}$ and (171- $374)^{\circ} \mathrm{C}$ respectively. Also thermal analysis data showed that the prepared polymers have good thermal stability thus temperature of $(10 \%)$ weight loss of polymers $[\mathrm{C} 6,8,12]$, while the major weight loss of these polymer occurred at $(577)^{\circ} \mathrm{C} \quad,(638)^{\circ} \mathrm{C}$ and $\quad(550)^{\circ} \mathrm{C}$ respectively, as in Figures (8-10).

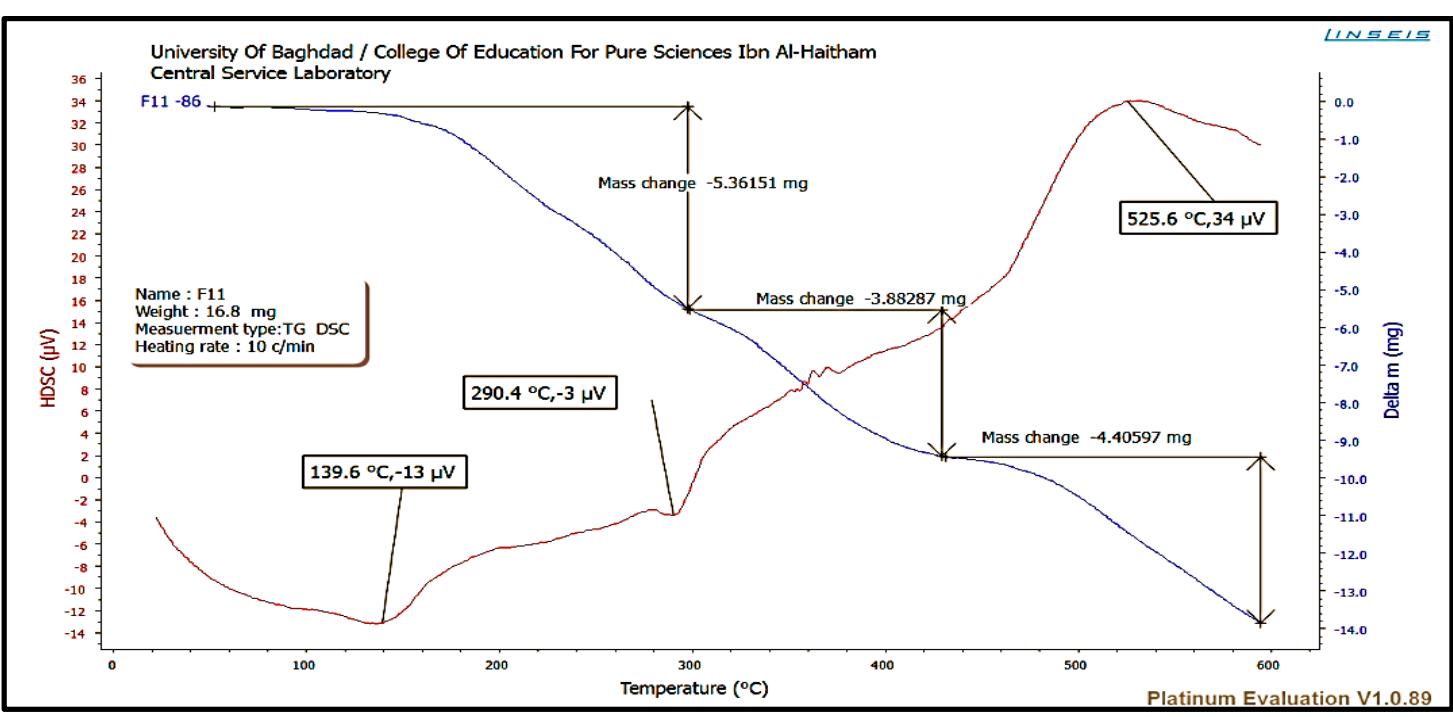

Fig.(8) : TGA and DSC of [ $\left.\mathrm{C}_{6}\right]$.

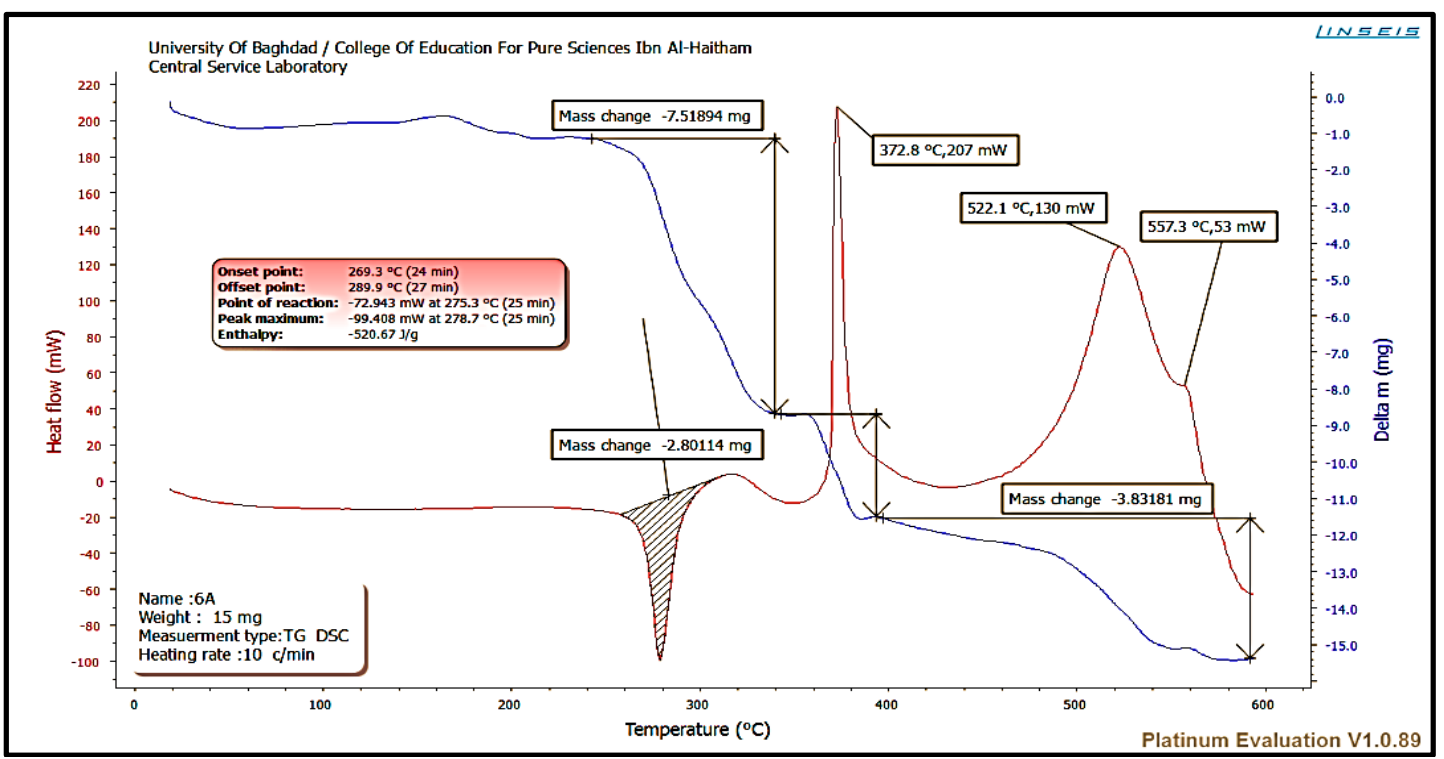

Fig.(9) : TGA and DSC of $\left[\mathrm{C}_{8}\right]$. 


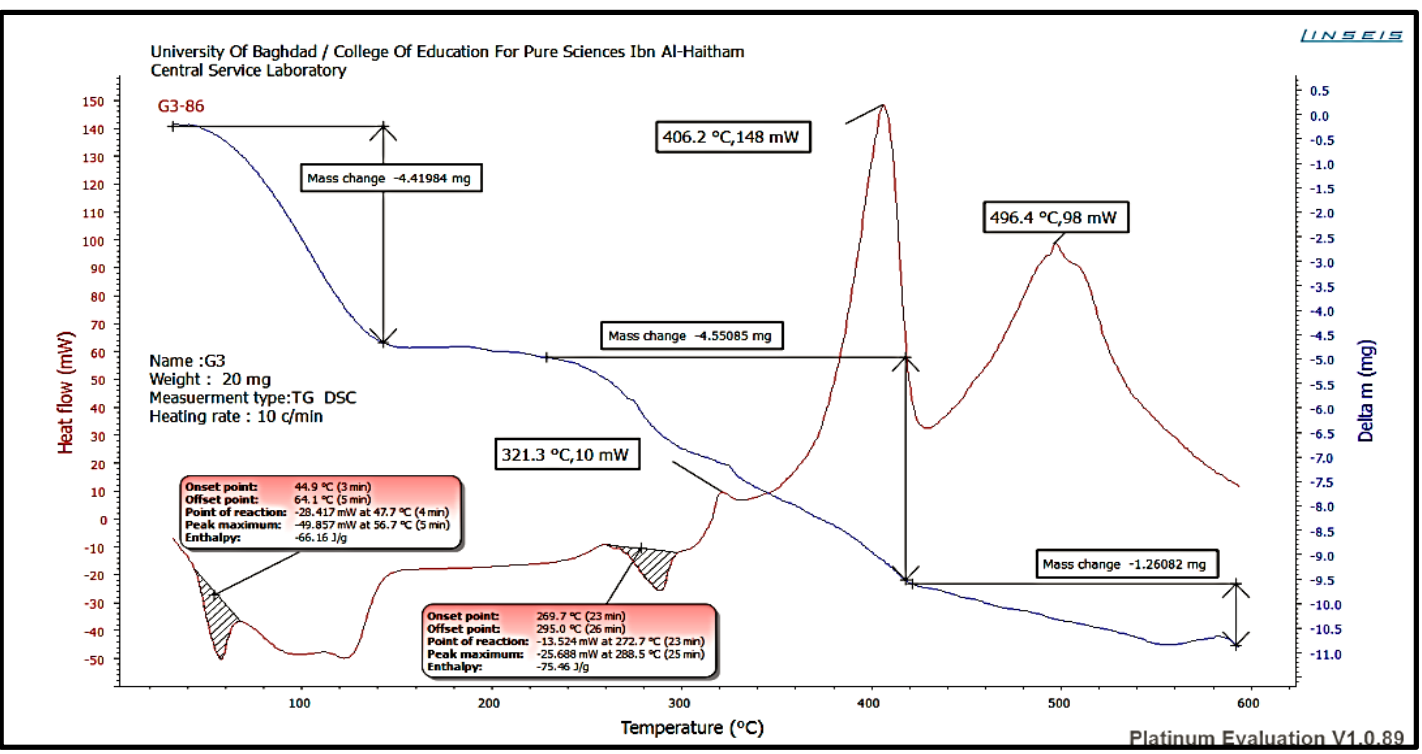

Fig.(10) : TGA and DSC of [ $\left.\mathrm{C}_{12}\right]$.

\section{X-Ray diffraction:}

$\mathrm{X}$-ray diffraction is used to identify the nature of the polymer weather crystalline or amorphous. All the prepeared polymers $\left[\mathrm{C}_{6^{-}-15}\right]$ are crystalline, as in Figer(11).

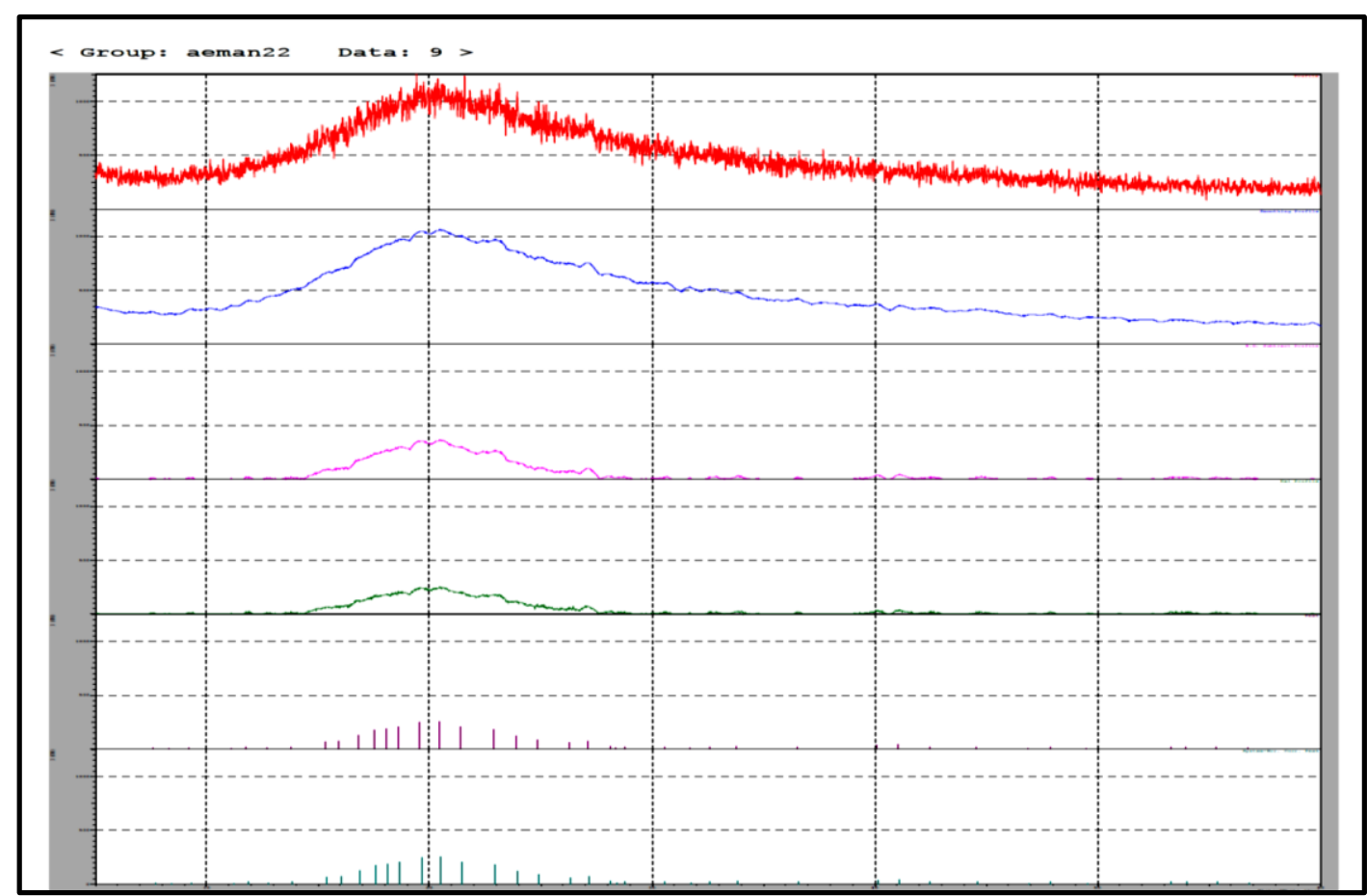

Fig.(11) : X-ray diffraction of polymers [ $\left.\mathrm{C}_{6^{-15}}\right]$

\section{References:}

[1] Benjamin, D. F. , Pathiraja ,A. G.and, Laurence, M. 2015. Biomedical applications of polymers derived by reversible addition fragmentation chain-transfer (RAFT). Adv. Drug Deliv. Rev. :1-12. http://dx.doi.org/10.1016/j.addr.2015. 05.016 .

[2] Charles , G. G. and Keith , E. B. 2009. Biologically Active Modification of Poly vinyl Alcohol : The Reaction of Phenyl Isocyanate with 
Polyvinyl Alcohol.121, Chapter 7 : 83-102. ACS Publication.

[3] Al-Kaddimy H. A. 2006 ,Synthesis and characterization of benzylidene$[1,3,4]$ thaidiazol- 2-yl-amine. AJPS, 3(1):32-39.

[4] Mustafa,M,M.,Alaa,H., Jawad,J, J. and Shneine,M, K. 2012 .Synthesis, characterization and evaluation of biological activity of new heterocyclic compounds containing 1,2,4- triazole and 1,3,4-thiadiazole rings. IJASTNET. 2(10):155-164.

[5] Bayram, G;Nevin ,T. and Esin, K; 2014.Synthesis, characterization, surface morphology properties and effects of annealing temperature on optical properties of poly(2-(((5phenyl -1,3,4-thiadiazole-2-yl)imino) methyl) phenyl methacrylate) (PTMPMA). Polym. Bull. 71:29452961.
[6] Sayyah, M. and Mohamed, S. M. 2015.Preparation kinetics and characterization of poly o-hydroxy aniline in aqueous hydrochloric acid solution using $\mathrm{K}_{2} \mathrm{Cr}_{2} \mathrm{O}_{7}$ as oxidizing agent. OSR-JAC. 8(2) : 28-43.

[7Mohamed, M, J; Jassem, I, K, and Muhanned ,A ,2013, Synthesis and Characterization of Five, Sevene Heterocyclic Membered Rings . J. Baghdad for Sci. 10(3) : 803-817.

[8] Nagham, M., Rasmey, J and Ali, F. 2014. Chemical Properties and Bioactive Study of (Benzanil and Oxazepam) Derivatives. Acta. Pharmica. ,1(1):8-15.

[9] Radhakrishnan,S, Akbary, I., Ahmady, A and Joseph, S. 2011. Synthesis and antimicrobial activity of a new series of 1,4 dihydropyridine derivatives. J. Serb. Chem. Soc. 76(1):1-11.

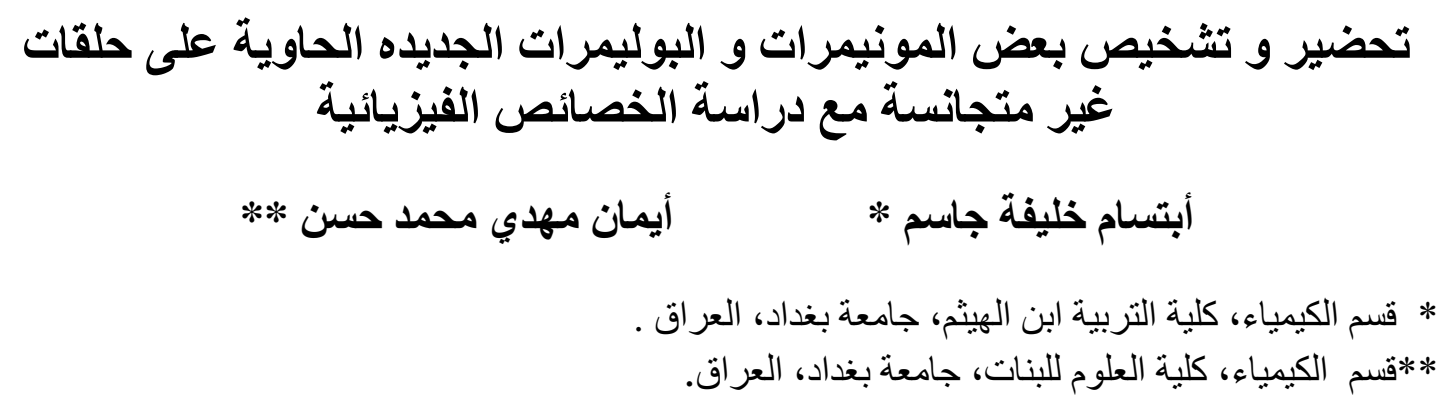

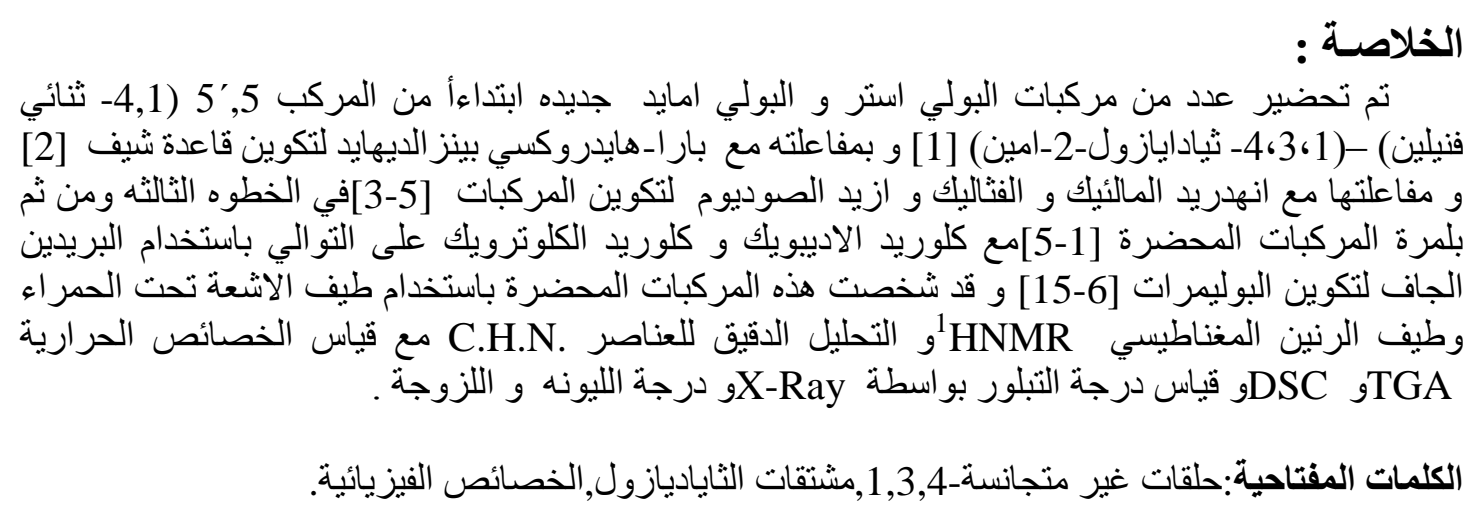

